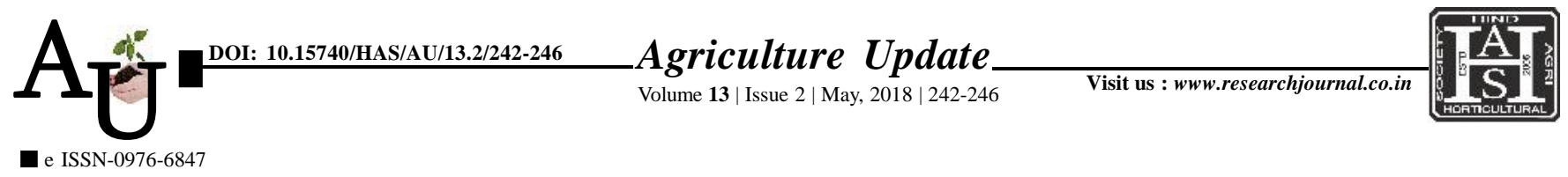

\title{
Research Article: Cost, returns and resource use efficiency in milk production by the members of milk producers co- operative societies in Dharwad district of Karnataka
}

\author{
Priyadarshini C. Gadad and L.B. Kunnal
}

Article Chronicle: Received :

27.12.2017;

Revised :

13.04.2018;

Accepted :

28.04.2018

KeY Words:

Cost, Returns, Milk

production, Member

farmers, Resource use

efficiency

Author for correspondence :

Priyadarshini C.

Gadal

Department of

Agricultural Economics,

College of Agriculture,

University of

Agricultural Sciences,

Dharwad (Karnataka)

India

Email:chintipriya@

gmail.com

See end of the article for

authors' affiliations
SUMMARY : An attempt has been made in this study to estimate the costs and returns in milk production and to analyze resource use efficiency in milk production in Dharwad district. Multistage sampling procedure was followed for selection of 120 sample Dairy farmers. The data pertained to the agricultural year 2014-15. Budgeting technique and Functional Analysis (Cobb-Douglas production function) were used to analyze the data. The total cost was Rs. 42342.85.The gross return obtained per animal per year was Rs. 52875.00 in which the sale of milk contributed the maximum share, the B:C ratio obtained was 1.25. The net returns per animal per year were Rs. 10532.15. The regression co-efficients of all the resources used in milk production were positive except grains $(-0.113)$. In this production function the regression co-efficients of concentrates and green fodder were found to be statistically significant at 5 per cent level of significance and for other resources like grains and dry fodder they were found to be non-significant. The co-efficient of multiple determination $\left(\mathrm{R}^{2}\right)$ was 0.802 indicating good fit of the model. The returns to scale (0.818) were found to be decreasing. The MVP to MFC ratio indicated that the ratio was greater than unity for concentrates and green fodder. Ratio was less than unity and negative in grain cost (-1.21). And also in case of dry fodder the ratio was found to be less than unity $(0.17)$. Thus, the results of the study brings that, the net returns in milk production can be increased by reducing the cost of inputs and farmers are advised to use of these resource optimally in production of milk.

How to cite this article : Gadad, Priyadarshini C. and Kunnal, L.B. (2018). Cost, returns and resource use efficiency in milk production by the members of milk producers co-operative societies in Dharwad district of Karnataka. Agric. Update, 13(2): 242-246; DOI : 10.15740/HAS/AU/13.2/242-246. Copyright@2018: Hind Agri-Horticultural Society. 